\title{
Religiosity and female participation in sport: exploring the perceptions of the Turkish university students
}

\author{
Turkmen M. ${ }^{\mathrm{ABCDE}}$ \\ School of Physical Education and Sport, Bartin University, Turkey
}

Authors' Contribution: A - Study design; B - Data collection; C - Statistical analysis; D - Manuscript Preparation; E - Funds Collection.

\begin{abstract}
Purpose: $\quad$ This exploratory study tried to find out religiosity levels and perceptions of Turkish university students on female participation in sport. It also aimed to point out the possible relationship between religiosity and female participation in sport.

Material: $\quad$ For this purpose, 412 university students attending to different faculties in Bartin University in Turkey completed Religiosity Inventory and Female Participation in Sport Questionnaire. The findings derived from both scales were evaluated using SPSS 22.0 program through descriptive statistics, t-Test and Anova Tests, and the relationships between two scales were calculated using Pearson Correlation Test and Regression Analysis. Gender and field of study were used as variables to elaborate the results of the scales.

Results: $\quad$ According to the findings of the research, it was found that the university students had very high religiosity level and very positive perception of female participation in sport. Moreover, the study pointed out there is a weak positive correlation between the religiosity and female participation in sport which was contradictory to the study hypotheses of this research.

Conclusions: As a conclusion, this study conveyed that religiosity does not have a negative effect on the female participation in sport.

Keywords: $\quad$ religiosity, spirituality, female participation in sport, gender equality, university students
\end{abstract}

\section{Introduction}

Religion plays a key role in the lives of individuals in today's society, but its function is not limited to the individuals at all. Religion affects the relationships between individuals, societies, and even states, therefore, is efficient in all domains of life. It is well-known that big majority of the world population identifies itself with a religion. The level of religiosity differs from one to another, but any level of religiosity has a direct influence on the behaviors, attitudes, feelings, and thoughts of individuals.

Female participation in sport is another topic on which sociologists and sports scientists have concentrated during the last few decades. Within the Muslim majority populated countries, female participation in sport has a primary importance due to the various number of constraints when compared to other countries with different sociological and religious backgrounds. Therefore it has primary importance to try to identify any kinds of relationships between religiosity and female participation in sport in Muslim countries.

\section{Literature and Theory}

Religiosity, spirituality, and religiousness

Altunsu-Sonmez [1] underlined that social scientists had conducted many studies on religion and each discipline had employed its own approach in the process of understanding and explaining the concept. Anthropology and sociology sciences are used when studying religion, its origin, its social effects and its functions. Religiosity studies, however, are reviewed by using the sciences of sociology and psychology, since religiosity involves socio-psychological elements. Many researchers (e.g.; [24]) stated that religion is not only an individual feeling or experience but also a sociological phenomenon including

(C) Turkmen M., 2018

doi:10.15561/20755279.2018.0405 any kinds of beliefs, customs, and traditions of social groupings. For this reason, when conducting studies on religion and especially on religiosity, it is vitally important that psychology and sociology be reviewed together [1].

In order to establish a balance between the psychological and sociological aspects of the definitions, Allport and Ross [5] applied intrinsic and extrinsic religious orientation categorizations. According to these authors, intrinsically oriented individuals find their master motive in religion. Other needs are of less ultimate importance and are brought into harmony with the religious beliefs and prescriptions. Such kinds of people are privately religious having private, personal and transcendent experiences easily and often, accepting and making use of these experiences [6]. On the other hand, extrinsically religious oriented individuals also turn to God, but without turning away from themselves [5]. That means they are disposed to use religion for their own ends, such as, to provide security, status, etc. These individuals use religion for their benefits [5] and accept the conceptualization of the religion as, all of the symbols, ceremonies, words, etc. as can be seen from many people in many cultures [6]. Other than these points, the degree of cohesion of religion with the social structure can have varying effects on the religiousness of the individual [7]. Accordingly, when religion turns into a separate institution, as in secularism, its effects will depend on the differential construal of the individuals [8]. As a common definition, religiosity was defined as the adherence to religious dogma or creed, the expression of moral beliefs, and/or the participation in organized or individual worship or sacred practices. Anyone or all of these qualities may be present and the construct was measured in two dimensions as private and public religiosity [9].

Allport and Ross [5]'s theory and conceptualization of intrinsic and extrinsic religious orientations have been 
the backbone of empirical research in the psychology of religion [10]. The research conducted in Muslim majority countries (e.g. in Iran and Turkey) proved that Allport's conceptual framework was supported cross-culturally and these concepts were relevant to the Muslim psychology of religion as well [11,12].

In most of the literature, religiosity, spirituality, and religiousness have been used interchangeably although each word has different implications. Gallagher and Tierney [13] stated that religiousness and religiosity are used to define an individual's conviction, devotion, and veneration towards a divinity. However, in its most comprehensive use, religiosity can encapsulate all dimensions of religion, yet the concept can also be used in a narrow sense to denote an extreme view and over dedication to religious rituals and traditions. This rigid form of religiosity, in essence, is often viewed as a negative side of the religious experience; it can be typified by an over-involvement in religious practices which are deemed to be beyond the social norms of one's faith [13]. That's why more people nowadays prefer to use spirituality in order to avoid misconceptions about institutional religions. Spirituality has become another term used interchangeably for religiosity or religiousness. However, these two terms may reflect different states of feelings when they are related to religions. Zwingman et al. [14] claimed that there are a growing number of persons, in particular in the so-called Western world, who identify themselves as "spiritual" or even as "spiritual, but not religious". According to Rasool [15], when it comes to Muslim context, there is no distinction between spirituality and religiosity. However, Jafari et al. [16] underlined that while spirituality and religion may not be differentiated in an Islamic context; spiritual care consists of more than just religious care. It is understood that from an Islamic point of view, spirituality and religion are often intertwined with one another and pervade all aspects of a person's life, but when it comes to healthcare context, spiritual care does not necessarily equate with religious care [15-17].

In order to measure religiosity/spirituality, many instruments have been developed so far. The instruments at the beginning were designed for Christianity and then adapted to the context of other religions. Studies on measuring religiosity got widespread in the second half of the twentieth century and reached the peak during the 1980s and 1990s [18]. The instruments of religiosity/spirituality have been moved from simple uni-dimensional scales to complex multi-dimensional scales; as Wach (1944) suggested three factors, Lenski (1961) four, Glock and Stark (1965) five, King (1967) nine, Hunt (1972) eleven dimensions [19].

The first attempts to develop religiosity scales in Turkish literature were conducted by Mehmet Taplamacioglu in 1962 and Erdogan Firat in 1977. These studies fell behind their period in terms of their methods and technical infrastructure [20]. The first and the most important study on measuring religiosity is the 'A Scale of Religiosity' created by Kayhan Mutlu in 1989 [21], which was the first study in Turkey to conduct validity and reliability tests. Moreover, the reliability coefficient of the scale was calculated as 0.94 which is a rather high score [21]. In this present study, the "Religiosity Inventory" which was developed by Kula [22] being strongly inspired by Mutlu [21] and finally revised by Aydemir [23] was used.

Gender equality and female participation in sport

Women had always been associated with genderbased characteristics and had to strive very hard to have an equal role in all domains of life when compared to men. In traditional societies, women always had a primary responsibility as a 'wife' and 'mother' which resulted in the exclusion of women in many social events, and of course main sports activities. Even the Olympic movement was very discriminative at the beginning and it took a very long time for female athletes to be represented almost equally in the Olympic Games. In Paris Olympic Games in 1900, 22 women participated for the first time which was only 2.2 percent of the total athletes. This trend grew up steadily, and finally in Rio Olympic Games in 2016, of the 11,444 athletes competing, 5,176 were women (45.2 percent) which has been the peak level of the Olympic history. IOC also took a historical decision in 1991 stating that any new sport seeking to be included on the Olympic programme had to include women's events.

Although female participation in sport is growing up, this is the case primarily in those sports considered feminine. Various studies among different demographic groups stated that people identify sport disciplines as masculine, feminine, or neutral [24]. Koivula [25]'s research involving 400 university students found that participants categorized sports as feminine, masculine, or gender-neutral based on their perceptions of the sports' aesthetics, speed, and risk. Sports such as tennis, volleyball, and swimming were ranked as neutral, gymnastics and aerobics were ranked as feminine, and baseball, soccer, and football were typed as masculine. Respondents incorporated the perceived purpose of a sport and its risk when assigning labels. Koivula [25] points out that definitions of a gender-appropriate sport can change because gender is constructed based on historically and culturally specific conditions. Channon [26] conveyed that mixed-sex training for challenging orthodox Western constructions of gender resulted with positive results. Anyhow, men still have a chance to practice a greater number of sports than women making gender equality not entirely attained. The governments all around the world, international policymakers such as United Nations and European Council, the world leading sport organizations are all concentrated on policy interventions in the area of gender equality in sport [27].

Female participation in sport in the Turkish and Muslim context

In considering how women's participation in sport is influenced by Islam, it must be stated first of all that there is no general prohibition of sport (in a broad sense) in Islam, and this includes girls' and women's sport [28, 29]. Many Muslim scholars so far emphasized that health and fitness are equally important for both sexes and must be maintained by regular physical activity. It is frequently pointed out in this connection that Prophet Mohammed himself recommended horseback-riding, swimming, and 
archery. Leila Sfeir and others infer from this that Islam originally showed a favorable attitude towards women's physical activities, but certain religious elements, such as Islamic fatalism and Hindu mysticism, have had negative effects on general access to sport [30].

Harkness [31] conducted a research on the cultural barriers to female sport participation in Qatar. This study clearly concluded that even women with high degrees of religiosity, including those who quit teams or stopped playing sports, insisted that religion was not the reason. All interpreted Islam as wholly supportive of female athletic activity. Playing sports did not make them feel less religious or in violation of Islamic principals at all.

After studying Islamic sources and authorities Shahiza Daiman [32] concluded that physical activities ought to be obligatory for women for reasons of health. Nevertheless, in several countries, women's sport (in a broad sense) is regarded as incompatible with the values and the concept of femininity prevailing in Islam, which forces women into subordination, dependence, and restriction of their roles to the house and family [30,32]. In sport and physical education girls and women must observe the precepts of Islam and maintain the honor of their families, which means above all that they must keep their bodies covered and not come into contact with other men [33]. That's why some studies carried out on Muslim minorities pointed out that some of the Muslim girls do not participate in physical education classes since the practices and values of physical education are not perceived to be compatible with their cultural traditions and beliefs. Girls being together with boys for activities like dancing and swimming [34], being physically active during Ramadan [29], and wearing the physical education kit [35] were considered as some of the barriers for girls' participation in the classes. Another study conducted in Pakistan on university students depicted that socio-cultural barriers are one of the main constraints of sport participation which would be more evident among female participants [36].

Various studies showed that athletes and coaches may use religion as a psychological support tool as they face stressors and challenges during training sessions and especially in competition [37-39]. They may also use aspects of religious practice to produce team cohesion [40]. What's more, a study found out that those who are spiritual and/or religious indicate better outcomes of mental health in a Muslim society [41]. Najah et al. [39] stated that future studies on Muslim population require looking at elements accounting for these associations and need to be responsive to cultural and theological matters in their assessment.

Turkey is a Muslim populated secular country and Turkish women have a modern lifestyle but are also attached to their traditions and customs. According to Inal [42], as Turkish women become educated and economically independent, they gain the chance to have a much more modern lifestyle, but the essence of their traditions and customs may still be definitive in their daily attitudes and lives. This is also evident in sport participation as the rate of female athletes decreases in eastern and rural parts of the country [42]. In an analysis of the prospects and the barriers facing Turkish women in sport, one must take into consideration the great differences between orientations and the reality of living conditions in Turkey, which depend on where a person lives and to what social class he or she belongs [28]. In general, however, it can be stated that participating in sport has never been an integral part of Turkish culture [28].

During last few decades, female athletes have increasingly started taking part in sports which have been traditionally regarded as masculine sports (e.g., wrestling, weight-lifting, kick-boxing, bodybuilding). However, many sports have been considered inappropriate for women, and women who engage in gender-inappropriate types of sports are often perceived as acting outside of their gender role [43]. Consequently, they are treated as behaving immorally. It can be assumed that the close association between the attributes required for sport and the traditional concepts of stereotypical gender roles contribute to this attitude. The participation of women and men in the social institution of sport and the very shape of that institution are partly determined by the definitions of what men and women ought to be in society [44]. Turkey is a very diverse country and the participation in sport, as well as the general practice and experience of physical activity, varies considerably in the various regions of Turkey [28,42]. The number of female athletes' in martial sports such as taekwondo, karate, and judo is growing tremendously which proves that an increasing number of women prefer to participate in sports traditionally dominated by men. It is also a reality that the society is changing, younger generation is more active in sport and families started to encourage their children especially girls, to enjoy sport, because sport is considered something positive. This continuing transformation and modernization process has led researchers to investigate the institution of sport as an important arena of gendered cultural practices in Turkish society [43].

According to the statistics taken from General Directorate of Sport of Turkish Ministry of Youth and Sport, by the end of 2017 only one-third of the licensed athletes are females (1,469,314 female athletes and 2,959,521 male athletes). These figures show that female participation in sports is exactly the half of male participation who are registered under 58 national sport federations.* Although this percentage seems to be negative for women, it is quite positive as this rate has raised from 27,96\% in 2009 [42] up to $33,17 \%$ in 2017. Out of 58 calculated national federations, when the percentage of female athletes taken into consideration, only 5 of them have dominantly more female athletes which are namely; Gymnastics Federation (62\%), Volleyball Federation (61\%), Folk Dance Federation (60\%), Dance Sports Federation (59\%), and Skating Federation (58\%). On the other hand only 7 of them can be regarded as neutral; Equestrian Federation (50\%), Tennis Federation (46\%), Badminton Federation (43\%), Swimming Federation (43\%), Curling Federation (42\%),

\footnotetext{
* This data was taken from the website of General Directorate of Sport and excludes licenses registered in Basketball, Football, and School Sports Federations (http://sgm.gsb.gov.tr/Sayfalar/175/105/Istatistikler).
} 
Orienteering Federation (40\%), and Fencing Federation (\%40).

It is noteworthy to point out that women had quite important successes in elite sports which create a positive impact on the perceptions of the society. Although women do still face various forms of discrimination, women have reached an important position in elite sport in Turkey, not the least because female athletes have been successful and thus have gained fame for the country [45]. In 2012, for the first time in Olympic history, the number of Turkish women was higher than the number of men, and women achieved to gain three of the five medals for Turkey. Besides, female volleyball teams both national and club level had outstanding results during last ten years. In the last eight seasons (between 2008 and 2016), Turkish teams managed to go the final fours of European Champions League, with two teams in five seasons, with one team in rest three seasons and won the cup four times. Turkish female volleyball club teams also managed to won World Clubs Champion title for four times during the same period. In a recent study, Bastug et al. [46] outlined that Turkish women are getting more visible in the society through work-life and social activities including organizational sport and physical activities which help them eliminate prejudices, negative value judgments, and sexism.

\section{Purpose of the Current Study}

The current study aimed to investigate the associations between religiosity and female participation in sport through the perceptions of the university students in the Turkish context. This topic has never been studied before. Various researchers have carried out studies separately on female sport participation and religiosity, no specific study has explored both subjects together on a relational basis. To our knowledge, the present study is unique as it investigated the relationship between religiosity and female participation in sport in Turkey for the first time. Specifically, this research empirically tried to explore: 1) whether there are gender and field of study differences in perceptions of university students about female participation in sport; 2) whether there are gender and field of study differences in the religiosity levels of the university students; and 3) whether religiosity and female participation in sport has a relationship; or whether we could expect to find that religiosity may play a negative role in girls' and women's participation in physical/sport activities due to some restrictions, such as dressing codes, and some other psycho-social barriers widely observed in Muslim societies, although it was clearly stated in the literature that Islam does not prohibit participation to sport (in a broad sense), and this also includes girls' and women's sport $[28,29]$.

\section{Material and methods}

\section{Participants}

To explore the associations between religiosity and female participation in sport through the perceptions of university students, and their differences through gender and field of study variables, two different scales were adapted to 412 university students $\left(\bar{X}_{\text {age }}=20.4\right)$ attending to different faculties in Bartin University in Turkey during the spring term of 2016-2017 education season. During the data collection, 456 scales were returned by the students who attended the study on voluntary basis. All participants gave their informed consent for inclusion before completing the scales. After partially completed surveys were excluded, the number of usable responses dropped to 412, a response rate of $90.35 \%$. As the nonresponse/partial completing rate was so low (9.65\%), it was understood that students answered both scales voluntarily and sincerely. However, it must be noted that this sample cannot be considered representative of the whole university population across the country and needs to be verified with new studies conducted in other universities in different regions and especially those in metropolitan cities.

Table 1. Demographic information of the sample

\begin{tabular}{llll}
\hline Information & $\mathbf{f}$ & $\mathbf{\%}$ \\
\hline \multirow{4}{*}{ Gender } & Male & $\mathbf{2 1 7}$ & $\mathbf{5 2 . 7}$ \\
& Female & $\mathbf{1 9 5}$ & $\mathbf{4 7 . 3}$ \\
& Total & $\mathbf{4 1 2}$ & $\mathbf{1 0 0 . 0}$ \\
& Faculty of Education & 71 & 17.2 \\
& Faculty of Economics and & & \\
& Administration & 54 & 13.1 \\
& School of Physical & & \\
& Education and Sport (PES) & 84 & 20.4 \\
Faculty & Faculty of Islamic Sciences & 112 & 27.2 \\
& Other Faculties (Faculty \\
& of Letters, Faculty of & & \\
& Science, Faculty of & & \\
& Forestry) & 91 & 22.1 \\
& Total & 412 & 100.0 \\
\hline
\end{tabular}

As seen in Table 1, 217 male (52.7\%) and 195 female students (47.3\%) attended the study. Three faculties which had fewer students in the study sample (Faculty of Letters = 39 students, Faculty of Science $=27$ students, and Faculty of Forestry = 25 students) were gathered and calculated together. As religiosity is mainly associated with Faculty of Islamic Sciences, and sport participation with School of Physical Education and Sport, it was more important in this study to evaluate these two faculties separately both of which were expected to have meaningful differences when compared to others.

\section{Measurements}

Female Participation in Sport Questionnaire (FPSQ)

In order to gather data about the opinions of university students on female participation in sport, the "Female Participation in Sport Questionnaire” (FPSQ) which was developed by Kizilyalli [47] was applied to the sample. As the validity and reliability of the questionnaire were conducted on university students, this questionnaire was a very suitable measurement device for the actual study as well.

FPSQ is a 5-point Likert type scale (1 = totally disagree, 5 = totally agree) which consists of 39 questions to determine the participants' opinions on females' participation in sport activities. Regarding construct validity of the questionnaire, 
factor analysis, and item-total correlation tests were used. Results indicated that factor values ranged from 0.30 to 0.80 and item-total correlation values ranged from 0.32 and 0.73. The Cronbach's Alpha internal reliability coefficient was computed as 0.769. 39 items were gathered into a single factor.

Religiosity Inventory (RI)

In order to gather data about the religiosity levels of the university students, the "Religiosity Inventory" (RI) which was developed by Kula [22] being strongly inspired by Mutlu [21] and finally revised by Aydemir [2008] was used. RI developed by Kula was composed of 30 items in total, and Aydemir dropped two items, which were about Jumua (Friday) prayers as they were only addressing to males, and added two new items which were on hajj (pilgrimage) and zakat (alms) as they were more related to both sexes. This inventory was a 5-point Likert type scale ( 1 = totally disagree, 5 = totally agree) and its revised form was applied to the adults aged between 20 and 35, therefore it is an appropriate tool for the present study as well.

In order to determine the validity of the inventory, factor analysis, and item-total correlation tests were conducted and 5 items of the inventory were eliminated as their factor values measured different factors than the total inventory. The rest of the items' factor values ranged from 0.30 to 0.78. The Cronbach's Alpha internal reliability coefficient was calculated as 0.86 . In the present study, the inventory was evaluated as a single factor measurement device.

Statistical analyses

Statistical analyses were performed using the Statistical Package for Social Sciences (SPSS 22 Version). Descriptive statistics (means and standard deviations) were used to analyze the data. In order to test the RI and FPSQ results using the variables (gender and field of study), t-Test and Anova Tests were conducted. Test of Normality was conducted on both scales in order to verify normal distribution of data in both scales. Finally, Pearson Correlation test was conducted in order to find out the relationship between the two scales and Regression Analysis was conducted in order to explain the relationship between these scales.

According to Table 2, the Skewness and Kurtosis values of the data proved that the data derived from both scales had a normal distribution in the present study.

\section{Results}

This study tried to point out the relationships and differences of religiosity and female participation in sport through the eyes of Turkish university students using gender and field of study as the variables. A total of 412 university students were included in the study attending different faculties of Bartin University (Table 1).

Table 3 reports the results of religiosity levels and perceptions of female participation in sport of the university students according to the gender variable.

In Table 3, the total points and average scores of 412 university students were calculated separately for each scale. The score limitations and loads of both scales according to this formula, $n-1=5-1=0.80$, was calculated and classified in Table 4 (Kizilyalli 2014).

In Religiosity Inventory, the average score was found as 4.32 and the total inventory score as 108.10 . These results show that the students have a very high religiosity level. When it comes to the Female Participation in Sport Questionnaire, the average score was found as 3.23 and the total score as 126.24. These results also indicate that the students have a very positive perception of female participation in sport. Kizilyalli [47] conducted a research on 750 university students attending Ankara University and found positive perception of female participation in sport. Therefore, it can be stated that the students of Bartin University, in general, have more positive attitudes towards

Table 2. Test of Normality of the two scales

\begin{tabular}{llllll}
\hline & N & Skewness & \multicolumn{3}{c}{ Kurtosis } \\
& Statistic & Statistic & Std. Error & Statistic & Std. Error \\
\hline RI Avarege & 412 & -0.759 & 0.120 & 0.944 & 0.240 \\
FPSQ Avararege & 412 & 0.372 & 0.120 & 1.071 & 0.240 \\
Valid N (listwise) & 412 & & & & \\
\hline
\end{tabular}

Table 3. Total and average scores of the scales

\begin{tabular}{llllll}
\hline & N & Min.Mean-Sum & Max.Mean-Sum & Mean & Sum \\
\hline RI & 412 & $1.88-47$ & $5-125$ & 4.32 & 108.10 \\
FPSQ & 412 & $1.64-64$ & $4.67-182$ & 3.23 & 126.24 \\
\hline
\end{tabular}

Table 4. Classification of the scales

\begin{tabular}{llll}
\hline FPSQ & Total Score & RI & Total Score \\
\hline Negative & $0-38$ & Very Low & $25-50$ \\
Less Positive & $39-78$ & Low & $51-75$ \\
Positive & $79-117$ & High & $76-100$ \\
Very Positive & $118-156$ & Very High & $101-125$ \\
\hline
\end{tabular}


Table 5. t-Test results of the scales according to the gender

\begin{tabular}{llllllll}
\hline & Gender & $\mathbf{N}$ & $\bar{X}$ & ss & t & Sd & $\mathbf{p}$ \\
\hline RI & Female & 217 & 4.31 & 0.417 & & & \\
& Male & 195 & 4.33 & 0.475 & -0.520 & 410 & 0.604 \\
FPSQ & Female & 217 & 3.22 & 0.417 & & & \\
& Male & 195 & 3.24 & 0.433 & -0.352 & 410 & 0.705 \\
\hline
\end{tabular}

$p<0.05$

Table 6. Anova Test results of the scales according to the field of study

\begin{tabular}{|c|c|c|c|c|c|c|c|c|c|}
\hline \multicolumn{10}{|l|}{$\mathbf{R} \mathbf{I}$} \\
\hline Faculty & $\mathbf{N}$ & $\bar{X}$ & ss & Variance source & KT & Sd & KO & $\mathbf{F}$ & $\mathbf{p}$ \\
\hline Faculty of Education & 71 & 4.36 & 0.466 & between groups & 9.952 & 4 & 2.488 & 14.164 & 0.000 \\
\hline Other Faculties & 91 & 4.21 & 0.550 & & & & & & \\
\hline Faculty of Economics & 54 & 4.04 & 0.554 & within groups & 71.492 & 407 & 0.176 & & \\
\hline School of PES & 84 & 4.33 & 0.280 & & & & & & \\
\hline Faculty of Islamic Sc. & 112 & 4.52 & 0.235 & & & & & & \\
\hline Total & 412 & 4.32 & 0.445 & & 81.444 & 411 & & & \\
\hline \multicolumn{10}{|l|}{ FPSQ } \\
\hline Faculty of Education & 71 & 3.15 & 0.452 & between groups & 5.060 & 4 & 1.265 & 7.446 & 0.000 \\
\hline Other Faculties & 91 & 3.15 & 0.420 & & & & & & \\
\hline Faculty of Economics & 54 & 3.07 & 0.323 & within groups & 69.151 & 407 & 0.170 & & \\
\hline School of PES & 84 & 3.37 & 0.411 & & & & & & \\
\hline Faculty of Islamic Sc. & 112 & 3.32 & 0.416 & & & & & & \\
\hline Total & 412 & 3.23 & 0.424 & & 74.211 & 411 & & & \\
\hline
\end{tabular}

$p<0.05$

female participation in sport when compared to the students of Ankara University.

According to Table 5, there is no meaningful difference in religiosity levels and female participation in sport between female and male students. Therefore, it is understood that the religiosity levels of both sexes and their perceptions of female participation in sport is almost similar in the sample group of this study. In a previous study conducted by Akgul [48] on 197 male and 112 female participants, no meaningful difference was observed between religiosity and sport participation according to the gender variable.
Although the study was not limited with the perceptions of female participation in sport, but sport in general, its findings are similar with the findings of the present study. On the other hand, Kizilyalli [47] found a contradictory result as female students had more positive attitude than males about female participation in sport.

In Table 6, it can be seen that there are meaningful differences in both scales when the field of study is taken into consideration (RI: $F=14.164, p<.000$; FPSQ: $F=$ $7.446, \mathrm{p}<0.000$ ). In order to find out between which groups meaningful differences appeared, one of the Post-Hoc tests, 
Table 7. Correlation between two scales

\begin{tabular}{llll}
\hline & & RI Average Score & FPSQ Average Score \\
\hline RI Average Score & Pearson Correlation & 1 & $0.185^{* *}$ \\
& Sig. (2-tailed) & & 0.000 \\
& $\mathrm{~N}$ & 412 & 412 \\
FPSQ Average Score & Pearson Correlation & $0.185^{* *}$ & 1 \\
& Sig. (2-tailed) & 0.000 & \\
\hline
\end{tabular}

**. Correlation is significant at the 0.01 level (2-tailed).

Table 8. Regression analysis

\begin{tabular}{|c|c|c|c|c|c|c|c|c|c|}
\hline Mode & $\mathbf{R}$ & R-Square & $\begin{array}{l}\text { Adjusted } \\
\text { R-Square }\end{array}$ & Std Eror & $\begin{array}{l}\text { R-Square } \\
\text { Change }\end{array}$ & F Change & df-1 & df-2 & $\mathbf{P}$ \\
\hline 1 & 0.200 & 0.040 & 0.038 & 0.26782 & 0.040 & 17.021 & 1 & 410 & 0.000 \\
\hline \multirow[t]{2}{*}{ Mode } & & & Sum of Squares & df & Mean Square & $\mathbf{F}$ & & $\mathbf{P}$ & \\
\hline & \multicolumn{2}{|l|}{ Regression } & 122.08 & 1 & 1.331 & 122.028 & & 0.000 & \\
\hline \multirow[t]{2}{*}{1} & Residual & & 2940.85 & 410 & 0.193 & 7.173 & & & \\
\hline & Total & & 3062.94 & 411 & & & & & \\
\hline \multicolumn{10}{|c|}{ Dependent Variable: Religiosity } \\
\hline
\end{tabular}

Tukey HDS test, was conducted. According to the result of this test, differences between the faculties are listed below.

Differences in religiosity levels;

1. The average score of the students in Faculty of Education ( $\bar{X}=4.36$ ) is higher than the scores of the students in Faculty of Economics and Administration ( $\overline{\mathrm{X}}=$ 4.04).

2. The average score of the students in Faculty of Economics and Administration $(\bar{X}=4.04)$ is lower than the scores of students in Faculty of Education $(\bar{X}=4.04)$, School of Physical Education and Sport $(\bar{X}=4.33)$, and Faculty of Islamic Sciences $(\overline{\mathrm{x}}=4.52)$.

3. The average score of the students in School of Physical Education and Sport $(\bar{X}=4.33)$ is higher than the scores of the students in Faculty of Economics and Administration ( $\bar{x}=4.04)$, but lower than the scores of the students in Faculty of Islamic Sciences $(\bar{X}=4.52)$.

4. The average score of the students in Faculty of Islamic Sciences $(\bar{X}=4.52)$ is higher than the rest of the students in all other faculties.

Differences in the perceptions of the students on female participation in sport;

1. The average score of the students in Faculty of Education $(\overline{\mathrm{x}}=3.15)$ is lower than the scores of the students in School of Physical Education and Sport $(\overline{\mathrm{X}}=3.37)$.

2. The average score of the students in Faculty of Economics and Administration ( $\overline{\mathrm{X}}=3.07)$ is lower than the scores of the students in School of Physical Education and Sport $(\overline{\mathrm{X}}=3.37)$ and Faculty of Islamic Sciences $(\overline{\mathrm{X}}=3.32)$.

3. The average score of the students in School of Physical Education and Sport $(\overline{\mathrm{X}}=3.37)$ is higher than the scores of the students in Faculty of Economics and Administration ( $\overline{\mathrm{X}}=3.07)$, Faculty of Education $(\overline{\mathrm{X}}=3.15)$, and Other Faculties (Science, Letters, and Forestry) ( $\overline{\mathrm{X}}=$ 3.15).

4. The average score of the students in Faculty of Islamic Sciences ( $\bar{x}=4.32)$ is higher than the scores of the students in Faculty of Economics and Administration ( $\overline{\mathrm{X}}=$ 3.07), Faculty of Education ( $\bar{X}=3.15)$, and Other Faculties (Science, Letters, and Forestry) $(\overline{\mathrm{x}}=3.15)$.

Therefore, the comparison of the average scores between the faculties confirmed that religiosity level is the highest in the students attending to Faculty of Islamic Sciences, and perceptions on female participation in sport is the highest among the students in the students attending to School of Physical Education and Sport.

Table 7 indicates that there is a positive weak correlation ( $r=0.185$, significant at 0.01 level) between religiosity levels of the students and their perceptions on female participation in sport which is contradictory to the study hypothesis. Although religiosity has a very weak positive effect, it can be stated that more religious students have more positive attitudes towards women's participation in sport activities. This finding is also contradictory to the results of the study conducted by Akgul [48] which found no meaningful difference between religiosity and sport participation. Although that study was not solely on the perceptions of female participation in sport, but sport participation for both sexes, its findings can be compared to the present study. According to the correlation tests conducted by Akgul [48], religiosity had no effect on sport participation, either positive or negative. Similarly, Bastug et al. [46] could not find any meaningful relationships between doing exercises variable and religiosity.

Table 8 proves the meaningfulness level of the model through the calculation of the F score. In this study, as F 
value ( $\mathrm{F}=7.173, \mathrm{P}<0.000$ ) was found to be meaningful, the total model is approved statistically meaningful in terms of the relationship between the two scales. Adjusted $\mathrm{R}$ Square value was found 0.038 which points out that $3.8 \%$ of the students' perceptions on female participation in sport can be explained as a direct result of the changes in their religiosity levels.

\section{Discussion}

Christl et al. [49] stated that there had been little research examining the complexity of the relationships linking gender and religiosity, and found that religiosity, in general, plays a more central role in the lives of girls than of boys. However, while the results show that girls are more interested in religious issues, believe in religious ideologies to a greater extent and place greater value on private religious practice such as prayer, there is neither gender difference in public religious practice, nor do girls report having more religious experiences than boys. This finding supports the idea that gender differences have been exaggerated in the literature [49]. Bastug et al. [46] were the first to investigate correlations between religiosity and the sub-factors of ambivalent sexism in Turkey. Their study found no significant difference between males and females for the correlation of religiosity and hostile sexism. In another study investigating the relationship between religiosity and gender conducted in German and Turkish individuals, at the behavioral level, the correlation between religiosity and gender egalitarianism was true for only Turkish respondents [50]. On the other hand, previous literature [51-53] had conveyed that hostile sexism is higher in males than females, but this attitude was not observed in sport domain [46]. All these studies confirm the findings of the present study as no meaningful difference was found in religiosity and female participation in sport according to the gender variable.

There has been a main interest in spirituality/religiosity and this interest has been mirrored in athletic activities. Many professional sports teams now hold church services on Sundays and many college teams have followed their lead. Pre-game prayer is also becoming customary for many teams. This includes the Texas Rangers professional baseball team who was featured in an article noting their religious character and values [54]. There are even organizations like the Fellowship of Christian Athletes and Athletes in Action that have been started to accommodate the growing number of athletes driven by their sport as well as spirituality [54]. A similar attempt in Turkey was the foundation of "Diyanet (Directorate of Religious Affairs) Sports Club" which was founded in 2007. The officials of Diyanet decided to found this club in order to go outside and compete with other religious communities in order to be taken seriously by the masses [55]. For this reason, Diyanet Sports Club had transferred world champion Moto GP driver Kenan Sofuoglu who competed in international arena on behalf of this club since 2009. In Turkey, many football stars appear in public prayer areas before competing in important matches. Therefore, it is out of question not to take religion into consideration in sport life.
Another issue closely interwoven with sport is body image which has positive relationship with religiosity. Demmrich at al. [56] conducted an exploratory study among 59 female Muslims between 17 and 46 years (n = 29 veiled, $\mathrm{n}=30$ non-veiled) in Turkey, measuring social appearance anxiety and religiosity. The results of this study showed that veiled women score much lower on social appearance anxiety than non-veiled women. Research in non-Muslim communities (e.g., [57-61]) also depicted that higher levels of spirituality predicted greater body satisfaction and self-esteem, and higher spirituality also predicted less appearance investment. Rossi and Castelli [60] carried out a comparative study on different religious groups and from another point of view; Lynch [62] stated that Physical Exercise and Health classes should be used to increase the spiritual experiences of the school children. Therefore, this perspective had underlined the reverse direction of the relationship between physical activity and spirituality/religiosity.

\section{Conclusion}

Very few studies (e.g. $[46,48,63])$ so far have focused on the relationship between religiosity and physical activity and sports in Turkey. Therefore this study has been a serious contribution to the literature as it elaborated a new dimension of sport, female participation, for the first time. This study is also significant as it tried to find out the possible associations between religiosity levels and perceptions of female participation in sport of the university students. Although a negative correlation was expected between religiosity levels and perceptions of female participation in sport, opposite result was found in this study. While the literature conveyed that the relationship between religiosity and sport participation is neutral, this study found a very weak positive relationship. The result found in this quantitative analysis does not mean that the meaningful relationship is applicable to all university students or all social groups. Future research should also apply qualitative methods of data collection and analysis in order to gain a better understanding of the subjective experiences of religiosity and the perceptions of female participation in sport.

The results of this study must be evaluated in light of its limitations. It involved university students in Bartin University, who cannot represent the total population of university students in Turkey. Students attending universities in metropolitan cities may have different opportunities, attitudes, and habits when compared to the students of Bartin University, which is located in a small city, therefore future studies should also focus on university students in different cities and regions as study samples. Another limitation is the understanding of sport as most of the students do not have a clear picture of the difference between sport and physical activity. Physical activity, as a direct result of its health benefits, is taken much more positively than regular sports activities and most of the students use both terms alternatively. This is why future studies need to clarify the distinction between physical activity and sport while exploring female 
participation in sport and/or physical activity and the relationship between them and religiosity.

Future research should also investigate health benefits of religiosity for athletes as there is a vast literature (e.g. $[39,64])$ depicting that religiosity play a central role in the process of reconstructing the coping strategies and reducing depression, anxiety and stress. Moreover, previous research conveyed associations between religiosity and substance misuse (i.e., alcohol, cigarette smoking) and potential doping behavior [65-67] which is another topic to be studied among Turkish athletes. Last, but not the least, Spirituality in Sports Test (SIST) which

\section{References}

1. Altunsu-Sonmez O. Religiosity, Self-monitoring and Political Participation: A Research on University Students. Doctorate Thesis. The Graduate School of Social Sciences of Middle East Technical University, Philosophy of Ankara; 2012.

2. Clark WH. The Psychology of Religion; an Introduction to Religious Experience and Behavior: What is Religion? New York: Macmillan; 1958.

3. Spinks GS. Psychology and religion, an introduction to contemporary views: Psychological Theories and Religion. London: Methuen; 1963.

4. Beit-Hallahmi B, Argyle M. The psychology of religious behavior, belief, and experience. London and New York: Routledge; 1997.

5. Allport GW, Ross JM. Personal religious orientation and prejudice. Journal of Personality and Social Psychology, 1967; 5: 432-443.

6. Maslow AH. The "core religious" or "transcendent experience”. Religions, Values and Peak Experiences (1929). Columbus: Ohio State University Press; 1964.

7. Glock CY. Dindarlığın boyutları üzerine [On the dimensions of religiosity]. (Trans: Y. Aktay and M. E. Koktas). Ankara: Vadi Yayınevi; 1998. (in Turkish)

8. Yildirim Z. Religiousness, Conservatism and their Relationship with Traffic Behavior. Master of Science Thesis. The Graduate School of Social Sciences of Middle East Technical University, Ankara; 2007.

9. Boswell GH, Kahana E, Dilworth-Anderson P. Spirituality and healthy lifestyle behaviors: stress counter-balancing effects on the well-being of older adults. J Relig Health, 2006; 45(4): 587-602, doi:10.1007/s10943-006-9060-7

10. Kirkpatrick LA, Hood RW Jr. Intrinsic-Extrinsic Religious Orientation: The Boon or Bane of Contemporary Psychology of Religion?” Journal for the Scientific Study of Religion, 1990; 29(4): 442-462.

11. Yaparel R. Dinin tarifi mümkün mü? [Is the definition of religion possible?] Journal of Faculty of Divinity of Dokuz Eylul University, 1987; 4: 403-417. (in Turkish)

12. Ghorbani N, Watson OJ, Ghramaleki RJ, Morris RW, Hood JR. Muslim attitudes towards religion scale: Factors, validity, and complexity of relationships with mental health in Iran. Mental Health, Religion, and Culture, 2000; 3(2): 125-133.

13. Gallagher S, Tierney W. Religiousness/Religiosity. In: Gellman M D, Turner JR (eds) Encyclopedia of Behavioral Medicine. New York, NY: Springer; 2013. doi:10.1007/9781-4419-1005-9

14. Zwingmann $\mathrm{C}$, Klein $\mathrm{C}$, Büssing A. Measuring religiosity/ spirituality: Theoretical differentiations and categorization of instruments. Religions, 2011; 2: 345-357. doi:10.3390/ was developed by Dillon and Tait [68] should be adapted to Turkish-Muslim context in order to measure religiosity in sports.

\section{Acknowledgments}

The author would like to thank the administration of Bartin University and to the students for their willingness to participate in this study.

\section{Conflicts of Interest}

The author declares no conflict of interest. rel2030345

15. Rassool GH. The crescent and Islam: Healing, nursing, and the spiritual dimension. Some considerations towards an understanding of the Islamic perspectives on caring. Journal of Advanced Nursing, 2000; 32: 1476-84.

16. Jafari N, Loghmani A, Puchalski CM. Spirituality and healthcare in Iran: Time to reconsider. J Relig Health, 2014; 53: 1918-22. doi:10.1007/s10943-014-9887-2

17. Ahmad M, Khan S. A model of spirituality for aging Muslims. J Relig Health, 2016; 55: 830-43. doi:10.1007/ s10943-015-0039-0

18. Mehmedoğlu AU. Dindarlığın peșinde: din psikolojisinde araştırma, ölçme ve yorumlama üzerine [After Religiosity: An Overview study on the Research, Measurement, and Interpretation in the Psychology of Religion], Islami Arastirmalar Dergisi, 2006; 19(3): 465-478. (in Turkish)

19. Himmelfarb HS. Measuring religious involvement, Social Forces, 1975; 53(4): 606-618.

20. Onay A. Dindarlık, Etkileşim ve Değişim Üniversite Öğrencileri Örneklemi [Religiosity, Interaction, and Change, The Sample of University Students]. İstanbul: Dem Yayınlar1; 2004. (in Turkish)

21. Mutlu K. Bir dindarlik ölçeği: sosyolojide yöntem üzerine bir araştırma [A scale on religiosity: a research on methodology in sociology]. Islami Arastirmalar Dergisi, 1989; 3(4): 194199. (in Turkish)

22. Kula MN. Identity and Religion: A Research on Adolescents. Philosophy of Doctorate Thesis. The Institute of Social Sciences of Uludag University, Bursa; 1993. (in Turkish)

23. Aydemir RE. The Relationships between Religiosity and Happiness: The Case of the First Adulthood. Master of Arts Thesis. The Institute of Social Sciences of Ondokuz Mayis University, Samsun; 2008.

24. Hardin M, Greer JD. The influence of gender-role socialization, media use and sports participation on perceptions of gender-appropriate sports. Journal of Sport Behavior, 2009; 32(2): 207-226.

25. Koivula N. Perceived characteristics of sports categorized as gender-neutral, feminine and masculine. Journal of Sport Behavior, 2001; 24(4): 377-393.

26. Channon A. Towards the "undoing" of gender in mixed-sex martial arts and combat sports. Societies, 2014; 4: 587-605. doi:10.3390/soc4040587

27. Svender S, Larsson H, Redelius K. Promoting girls' participation in sports: Discursive constructions of girls' in a sports initiative. Sport, Education, and Society, 2012; 17(4): 463-478, doi:10.1080/13573322.2011.608947

28. Pfister G. Doing sport in a headscarf? German sport and Turkish females. Journal of Sport History, 2000; 27(3): 497-524. 
29. McGee JE, Hardman K. Muslim schoolgirls' identity and participation in school-based physical education in England. SportLogia, 2012; 8(1): 49-71. doi:105550/sgia.120801. en.029M

30. Sfeir L. The status of Muslim women in sport: conflict between cultural tradition and modernization, International Review for the Sociology of Sport, 1995; 20(4): 283-306.

31. Harkness G. Out of bounds: Cultural barriers to female sports participation in Qatar. The International Journal of the History of Sport, 2012; 29(15): 2162-83. doi:10.1080/09 523367.2012.721595

32. Daiman S. Women in sport in Islam. ICHPER-SD Journal, 1995; 32(1): 18-21.

33. Bauer JL. Sexuality and the moral construction of women in an Islamic society. Anthropological Quarterly, 1985; 58(3): 120-29.

34. Dagkas S, Benn T, Jawad H. Multiple voices: improving participation of Muslim girls in physical education and school sport. Sport, Education and Society, 2011; 16(2): 223-239. doi:10.1080/13573322.2011.540427

35. Dagkas S, Benn T. Young Muslim women's experiences of Islam and physical education in Greece and Britain: a comparative study. Sport, Education and Society, 2006; 11(1): 21-38. doi:10.1080/13573320500255056

36. Marwat MK, Zia-ul-Islam S, Khattak H. Motivator, constraints, and benefits of participation in sport as perceived by the students. IntJSCS, 2016; 4(3): 284-294. doi:10.14486/IntJSCS517

37. Joseph E. The multi-dimensional relationship between religion and sport. Journal of Physical Education and Sport Management, 2012; 3: 1-7.

38. Jona IN, Okou FT. Sports and religion. Asian Journal of Management Science and Education, 2013; 2(1): 46-54.

39. Najah A, Farooq A, Ben Rejeb R. Role of religious beliefs and practices on the mental health of athletes with anterior cruciate ligament injury. Advances in Physical Education, 2017; 7: 181-190. doi:10.4236/ape.2017.72016

40. Lane K. Cossacks, holy bread, running shorts and energy gels, the race for religion in modern societies. [Internet]. 2014 [updated 2014 Feb 10; cited 2017 Nov 6]. Available from: http://esource.dbs.ie/bitstream/handle/10788/2260/ poster_lane_2014.pdf?sequence $=2$

41. Abu-Rayya HM, Abu-Rayya MH, Khalil M. The multireligion identity measure: a new scale for use with diverse religions. Journal of Muslim Mental Health, 2009; 4: 124138. doi:10.1080/15564900903245683

42. Inal HS. Women's and girls' sports in Turkey. Women in Sport and Physical Activity Journal, 2011; 20(2): 76-85.

43. Koca C, Asci FH, Kirazci S. Gender role orientation of athletes and nonathletes in a patriarchal society. Sex Roles, 2005; 52(3/4): 217-225. doi:10.1007/s11199-005-1296-2

44. Murphy PJ. Sport and gender. In: WM Leonard II (Eds.), A Sociological Perspective of Sport. New York: MacMillan: 1988. P. 256-277.

45. Pfister G, Hacisoftaoglu I. Women's sport as a symbol of modernity: a case study in Turkey, The International Journal of the History of Sport, 2016; 33(13): 1470-82. doi:10.1080 /09523367.2017.1293045

46. Bastug G, Bingol E, Yarali D. Investigation of senses of sexism and religiosity in terms of sports variable. Turkish Journal of Sport and Exercise, 2016; 18(1): 91-97. doi:10.15314/tjse.41788

47. Kizilyalli M. Opinions of Ankara University Students on Female Participation in Sporting Activities. Master of
Science Thesis. The Institute of Health Sciences of Ankara University, Ankara; 2014. (in Turkish)

48. Akgul MH. The Culture of Popular Sports and Religion. Master of Science Thesis. The Institute of Health Sciences of Selcuk University, Konya; 2014. (in Turkish).

49. Christl T, Morgenthaler C, Kappler C. The role of gender and religiosity in positive body image development among adolescents in Germany. Women's Studies, 2012; 41; 728754. doi:10.1080/00497878.2012.692575

50. Burn SM, Busso J. Ambivalent sexism, scriptural literalism, and religiosity. Psychology of Women Quarterly, 2005; 29; 412-418.

51. Sakall1-Uğurlu N. Ambivalent sexism inventory: a study of reliability and validity. Journal of Turkish Psychology, 2002; 17; 47-58.

52. Sakalli-Uğurlu N, Yalçın ZS, Glick F. Ambivalent sexism, belief in a just world, and empathy as predictors of Turkish students' attitudes toward rape victims. Sex Roles, 2007; 57: 889-895.

53. Diehl C, Koenig M, Ruckdeschel K. Religiosity and gender equality: comparing natives and Muslim migrants in Germany. Ethics and Racial Studies, 2009; 32: 278-301.

54. Prebish CS. Religion and sports: Convergence or identity? In: C.S. Prebish (Ed.), Religion and Sport: The Meeting of the Sacred and the Profane. Westport, CT: Greenwood Press; 1993. P. 50-76.

55. Bilgili A. Post-secular society and the multi-vocal religious sphere in Turkey. European Perspectives, 2011; 3(2): 131146.

56. Demmrich S, Atmaca S, Dinc C. Body image and religiosity among veiled and non-veiled Turkish women. Journal of Empirical Theology, 2017; 30(2): 127-147. doi:10.1163/15709256-12341359

57. Smith MH, Richards P, Maglio CJ. Examining the relationship between religious orientation and eating disturbances. Eating Behaviors, 2004; 5(2): 171-180. doi:10.1016/S14710153(03)00064-3

58. Mahoney A, Carels RA, Pargament KI, Wachholtz A, Leeper L, Kaplar M, et al. The sanctification of the body and behavioral health patterns of college students. International Journal for the Psychology of Religion, 2005; 15(3): 221238. doi:10.1207/s15327582ijpr1503_3

59. Boyatzis, C. J., Quinlan, K. B. Women's body image, disordered eating, and religion: A critical review of the literature. Research in the Social Scientific Study of Religion, 2008; 19: 183-208. doi:10.1163/ej.9789004166462.i-299.61

60. Rossi, G. Castelli, C. Religiosity and Body Image: A Comparison between Catholics, Muslims and Atheists in Italy. In: Proceedings of the IAPR Congress, Istanbul, August 2015. 2015. P. 99-100.

61. Goulet C, Henrie J, Szymanski L. An exploration of the associations among multiple aspects of religiousness, body image, eating pathology, and appearance investment. J Relig Health, 2017; 56: 493-506. doi:10.1007/s10943-016-0229-4

62. Lynch T. Investigating children's spiritual experiences through the health and physical education (HPE) learning area in Australian schools. J Relig Health, 2015; 54(1): 202220. doi:10.1007/s10943-013-9802-2

63. Calisir M. Investigation of the relationship between psychological health and religiousness in athletes. Master of Science Thesis. The Institute of Health Sciences of Sitki Kocman University, Muğla; 2014. (in Turkish)

64. Cummings JP, Pargament KI. Medicine for the spirit: Religious coping in individuals with medical conditions. 
Religions, 2010; 1: 28-53. doi:10.3390/rel1010028

65. Sekulic D, Kostic R, Rodek J, Damjanovic V, Ostojic Z. Religiousness as a protective factor for substance use in dance sport. J Relig Health, 2009; 48: 269-277. doi:10.1007/ s10943-008-9193-y

66. Zenic N, Stipic M, Sekulic D. Religiousness as a factor of hesitation against doping behavior in college-age athletes. $J$ Relig Health, 2013; 52: 386-396. doi:10.1007/s10943-0119480-x
67. Zvan M, Zenic N, Sekulic D, Cubela M, Lesnik B. Genderand sport-specific associations between religiousness and doping-behavior in high-level team sports. $J$ Relig Health, 2017; 56: 1348-1360. doi:10.1007/s10943-016-0254-3

68. Dillon KM, Tait JL. Spirituality and being in the zone in team sports: A relationship? Journal of Sport Behavior, 2000; 23(2): 91-100.

\section{Information about the author:}

Turkmen M.; http://orcid.org/0000-0003-4534-7553; turkmenm@yahoo.com; Head of Recreation Department in School of Physical Education and Sport, Bartin University; Agdaci Kampusu, 74100, Bartin, Turkey.

Cite this article as: Turkmen M.Religiosity and female participation in sport: exploring the perceptions of the turkish university students. Physical education of students, 2018;22(4):196-206. doi:10.15561/20755279.2018.0405

The electronic version of this article is the complete one and can be found online at: http://www.sportedu.org.ua/index.php/PES/issue/archive

This is an Open Access article distributed under the terms of the Creative Commons Attribution License, which permits unrestricted use, distribution, and reproduction in any medium, provided the original work is properly cited (http://creativecommons.org/licenses/by/4.0/deed.en).

Received: 12.05 .2018

Accepted: 02.06.2018; Published: 23.08.2018 